\title{
COVID-19 Pandemic in Democratic Republic of the Congo: An Opportunity for Economic Recovery
}

\author{
Modeste Ndaba Modeawi ${ }^{1}$, John Likolo Baya ${ }^{2}$, Bembi Bosso ${ }^{3}$, Jacquie Kangu Kobe ${ }^{4}$, \\ Lonas Mbaya Kusagba ${ }^{5}$,JP Mokombe Magbukudua ${ }^{6}$, Masengo Ashande Colette ${ }^{7}$, \\ Gédéon Ngiala Bongo ${ }^{8}$, Muhammad Ridwan ${ }^{9} *$, Koto-te-Nyiwa Ngbolua ${ }^{10^{*}}$ \\ 1,2,5Faculty of Law, University of Gbado-Lite, Gbado-Lite, Democratic Republic of the Congo \\ ${ }^{3}$ Higher Pedagogical Institute of Molegbe, Gbado-Lite, Democratic Republic of the Congo \\ ${ }^{4}$ Higher Institute of Rural Development of Mbandaka, Mbandaka, Democratic Republic of the Congo \\ 'Faculty of Agricultural Sciences, University of Gbado-Lite, Gbado-Lite, Democratic Republic of the \\ Congo \\ ${ }^{7,10}$ Faculty of Science, University of Gbado-Lite, Gbado-Lite, Democratic Republic of the Congo \\ ${ }^{8,10}$ Faculty of Science, University of Kinshasa, Kinshasa, Democratic Republic of the Congo \\ 'Universitas Islam Negeri Sumatera Utara, Indonesia \\ Email: jpngbolua@unikin.ac.cd
}

\begin{abstract}
:
The world is facing an unprecedented health crisis caused by the COVID-19 pandemic. The DR Congo with its 90 million inhabitants and more than 500,000 refugees from neighboring countries recorded the first confirmed case in Kinshasa on March 10, 2020. Currently, the country is counting 16,039 cases of infection, 566 cases of death and 13,536 cases of recovery according to the Technical Secretariat Response Team COVID-DRC, (December 23, 2020). After reporting the first case, Congolese government has taken protective health measures whereby it is in a worrying economic situation that was immediately noticeable by the increase in the rate of the foreign currency (the dollar) compared to the local currency. From an extroverted economy, the Covid-19 pandemic has put it in a situation of stagnation, which could lead country into an economic recession if this scourge persists.
\end{abstract}

Keywords:

covid-19; opportunity; economic recovery; DRC

\section{Introduction}

Africa will not escape the negative impact on its economies as the crisis is worldwide. Very quickly, and without even having been confronted with the magnitude of the cases found elsewhere, the economies of African countries are being hit hard by the effects of the pandemic - the slowdown observed in this area is a justification for this. The United Nations Economic Commission for Africa estimates that African countries should be prepared to see their growth halved to only $2 \%$ instead of the $4 \%$ initially forecast. This will have a negative impact on the income of countries that depend mainly on natural resources. China's economy will be severely affected: as the world's second largest economy (more than $16 \%$ of global GDP), the world's largest importer of raw materials, and the world's second largest consumer of oil, the global economy as well as the macroeconomic frameworks of both developed and developing countries will be impacted by the spread of the coronavirus, including the Democratic Republic of the Congo (DRC).

In view of its high vulnerability to exogenous shocks, DRC is exposed to high risks of disruption of its economic and social situation; if no solution is envisaged in the coming days, Africa will be severely affected. In addition to the contamination of the virus, which would directly affect the quality of life of households and the workforce, it should be noted that the 
balance of payments and the productive sectors that sell most of their products abroad, especially in China, remain the ways in which the corona virus pandemic tends to affect the economy of countries. Other aspects of the Congolese economy, notably public finances, the employment situation and certainly economic growth, will be affected by the shock of the corona virus with the risk of disrupting the stability of the macroeconomic framework. This will result in the human and social deterioration of living conditions, which are already not very good [1].

\section{Research Methods}

To study the impact of the corona virus on the economy of DRC, we relied on data related to the macro-economic framework, namely the economic growth rate, the trade balance, the inflation and exchange rates, we conducted a review search using different databases related to COVID-19, and economy of DRC.

\subsection{Conceptual Clarification}

The understanding of some concepts is vital before tackling the problem of economy.

\section{a. Economic Crisis}

It is a sudden slowdown of the general economic activity. It results in an increase in unemployment and bankruptcies. This situation can lead to social tensions.

\section{b. Economic Growth}

Is the acquisition over time of more goods and services without working more; it is a sustainable increase, accompanied by structural changes and leading to economic progress. It corresponds to an increase in the average productivity of labor and is translated into an increase in per capita income, which may be accompanied by a decrease in working time that could allow the same level of wealth to be maintained [2]. Growth is therefore an increase in GDP that benefits all categories of the population, notably through the reduction of poverty and inequality.

\section{c. Economic Recession}

The economic recession is a period of reduced economic activity that results in a decline in GDP over a period of at least two consecutive quarters. A recession is distinct from a simple economic slowdown, which is a decline in the rate of GDP growth over two consecutive quarters [3].

\section{d. Depression}

A decrease in production over a longer period of time; as experienced in the United States after the stock market crash of 1929.

\section{e. Inflation}

Inflation refers to an increase in the quantity of money, which mechanically raises the general price level of goods and services. Inflation makes economic growth unbalanced and causes stagflation, a situation where inflation and unemployment coexist.

After a comprehensive analysis of the aforementioned concepts and expressions, the following points are devoted to the existence and evolution of the COVID-19 in DRC, its impact on the Congolese economy and proposals for reviving this economy. 


\section{Discussion}

\subsection{Covid-19 Pandemic in DRC}

The COVID-19 pandemic in DRC is documented in the country as of March 10, 2020 , when a first case was confirmed. DRC thus becomes the 11 th African country affected by COVID-19. As of June 20, 2020, the Congolese Ministry of Health lists 5,826 confirmed cases, including 130 deaths and 841 recoveries. Most cases were reported in Kinshasa city while other cases were reported in different provinces. To date, 22 provinces were affected with a total number of 16,039 confirmed cases, 13,536 cured and 566 cases of death [4]. The statistical data showing the number of cases of infection due to COVID-19 in the different affected provinces of DRC are given in figure 1.

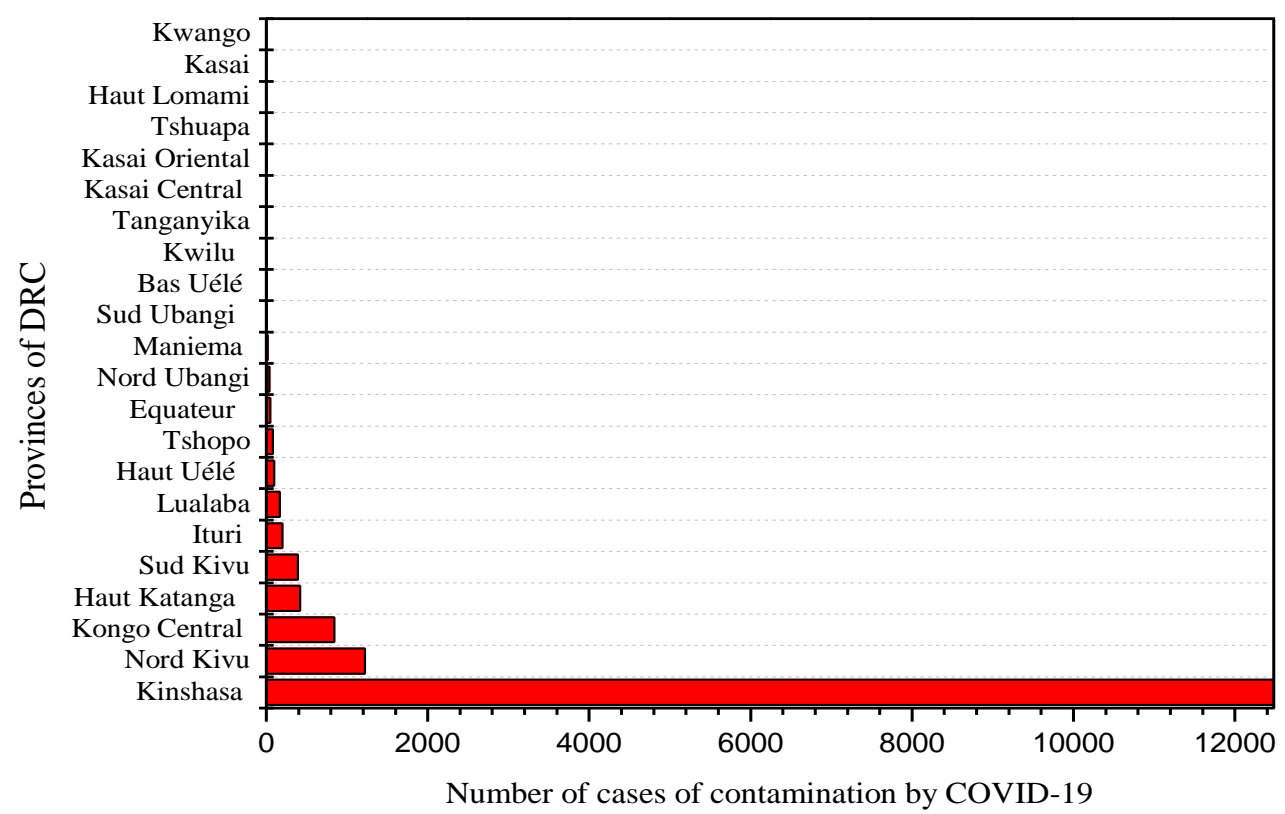

Figure 1. Statistical Table of the Number of Cases of Infection by Province due to Covid-19 since the First outbreak in Kinshasa on March 10 to December 23, 2020 (Source: Epidemiological Bulletin of National Institute of Biomedical Research INRB)

This figure revealed that Kinshasa is the province most affected by COVID-19 followed respectively by the province of Nord-Kivu, Kongo Central, Haut Katanga, SudKivu, Ituri, Lualaba, Haut-Uélé Tshopo, Equateur and Nord-Ubangi.

\subsection{The Covid-19 Pandemic and the DRC's Economy}

a. Economic situation of DRC before Covid-19

1. Recent Characteristics of the Congolese Economy

Congolese economy is underdeveloped because of the embryonic state of its industry and its heavy dependence on the primary sector, particularly the extraction of mineral resources. Although its share of growth declined sharply between 2018 and 2019, from 4.4 to 0.5 contribution points, it remains the main driver of the country's economy. The role played by the exploitation of mining resources is severalfold. Not only does it contribute to the direct creation of wealth and jobs, but it also supports other segments of the economy through its consumption of various services. It also contributes to the inflow of foreign currency and therefore its dynamism contributes to the balance of the foreign exchange market. [1]. 
Table 2. Breakdown of the growth rate from 2017 to 2020 (forecast)

\begin{tabular}{|l|l|l|l|l|l|l|l|l|l|}
\hline \multirow{2}{*}{ Year } & Primary & Mining & Secondary & Tertiary & Primary & Mining Secondary & Tertiary & Growth \\
\cline { 2 - 10 } & \multicolumn{5}{|c|}{$\%$} & \multicolumn{5}{c|}{ Points de croissance } \\
\hline 2017 & 59,5 & 52,5 & 31,6 & 31,9 & 2,22 & 1,96 & 1,18 & 1,19 & 3,5 \\
\hline 2018 & 81 & 75,8 & 12 & 8,6 & 4,7 & 4,7 & 0,7 & 0,5 & 5,8 \\
\hline 2019 & 19,5 & 10,8 & 34,8 & 36,9 & 0,9 & 0,9 & 1,6 & 1,7 & 4,6 \\
\hline $\begin{array}{l}2020 \\
\text { prev }\end{array}$ & & & & & & & & & 5,4 \\
\hline
\end{tabular}

(Source : Commercial bank of Congo BCC)

\section{Trade Balance}

Congolese trade balance in 2018 and 2019 indicates that more than $90 \%$ of the country's export revenues come from the sale of mining and hydrocarbon products abroad. It is also these revenues that support the level of foreign exchange reserves of the Central Bank of Congo (BCC) [1].

Table 3. Balance Commerciale Allant de 2018 à 2019

\begin{tabular}{|l|c|c|c|}
\hline & $\mathbf{2 0 1 8}$ & $\mathbf{2 0 1 9}$ & Variation (\%) \\
\hline Exportations (Millions USD) & $15.966,8$ & $15.031,3$ & $-5,9$ \\
\hline Mining and hydrocarbon & $15.826,8$ & $14.919,7$ & $-5,7$ \\
\hline Farm products & 124 & 100.7 & $-18,8$ \\
\hline Industrial products & 16,1 & 10.9 & $-32,0$ \\
\hline Importations (Millions USD) & $14.972,7$ & $14.631,7$ & $-2,3$ \\
\hline Consumer goods & 3555,2 & 3667,3 & 3,2 \\
\hline Energy & 1108,6 & 1068,7 & $-3,6$ \\
\hline Raw materials and semi-finished products & 3187,6 & 3573,2 & 12,1 \\
\hline Capital goods & 7121,2 & 6322,4 & $-11,2$ \\
\hline Balance & 994,1 & 399,6 & $-59,8$ \\
\hline
\end{tabular}

(Source : Commercial bank of Congo BCC)

Serological tests that can be used include ELISA, indirect hemaglutination, cellulose acetate precipitin, counterimmunoelectrophoresis, immunofluoroscent antibody and rapid agglutination tests. The results of serorological tests should be interpreted clinically by the patient because serum antibody levels remain high for several years after improvement or recovery. The test sensitivity is $95 \%$ and the specificity is more than $95 \%$ (Nusi, I.A. 2014).

Still in terms of transactions with the rest of the world, more specifically in terms of the capital account, there was a decline in the balance of operations. The latter fell from $0.9 \%$ to $0.3 \%$ of GDP due to a decrease in private transfers. Net foreign direct investment fell by $4.02 \%$ year on year. It should be noted that capital goods account for almost $50 \%$ of imports.

3. Inflation and Exchange Rate: 2017-2019

Table 4. Inflation and Exchange Rate from 2017 to 2019

\begin{tabular}{|l|c|c|c|c|}
\hline \multirow{2}{*}{ Year } & Inflation & Exchange rate & $\begin{array}{c}\text { Variation of } \\
\text { exchange rate }\end{array}$ & $\begin{array}{c}\text { Foreign exchange } \\
\text { reserve }\end{array}$ \\
\cline { 2 - 5 } & $\%$ & CDF/USD & $\%$ & in USD \\
\hline 2012 & 2.7 & 915.2 & & $1.271,80$ \\
\hline 2013 & 1.07 & 918 & -0.31 & $1.743,60$ \\
\hline 2014 & 1.03 & 925 & -0.76 & $1.645,15$ \\
\hline 2015 & 0.8 & 927 & -0.22 & $1.403,58$ \\
\hline
\end{tabular}




\begin{tabular}{|l|c|c|c|c|}
\hline 2016 & 11.45 & 1281 & -27.63 & 845,44 \\
\hline 2017 & 54,7 & 1650 & $-22,36$ & 844,02 \\
\hline 2018 & 7,22 & 1670 & $-1,20$ & 879,48 \\
\hline 2019 & 4,58 & 170 & $-2,05$ & 858,66 (before IMF) \\
\cline { 3 - 5 } & & & & $1.030,97$ (After IMF) \\
\hline
\end{tabular}

(Source: Commercial bank of Congo BCC)

Since the exchange rate is determined by the meeting of supply and demand for foreign currency, its behavior should be compared with the balance of trade. And since the country is very dependent on the outside world, particularly on food imports, the evolution of the consumer price index is to some extent linked to the exchange rate. The currency depreciation observed between 2016 and 2017 was the result of a decline in the supply of foreign currency - caused mainly by the drop in world mineral prices - while the demand for foreign currency on the foreign exchange market tended to increase due to speculation and mistrust among economic agents because of the fragile political and security situation. It is important to note that the relative macroeconomic stability observed between 2018 and 2019 was achieved at the cost of a high consumption of foreign exchange reserves, covering the significant deficits of the financial operations of the State, in a context of declining growth. The high consumption of foreign exchange reserves has also resulted in the postponement of the financing of investment spending. An analysis of the structure of government revenue indicates that a significant share of government revenue comes from the country's foreign trade transactions in customs and excise duties ( $\pm 25 \%$ of total revenue). Taxes related to foreign trade are estimated to account for almost $30 \%$ of tax revenues [1]. The contributions of financial authorities to government revenue in 2019 are given in table 5.

Table 5. Contributions of Financial Authorities to Government Revenue in 2019

\begin{tabular}{|l|c|c|}
\hline Financial agency & Fiscal return (in CDF) & Proportion (\%) \\
\hline DGI & 3.613 .123 & 51,4 \\
\hline DGDA & 2.009 .375 & 28,6 \\
\hline DGRAD & 1.114 .590 & 15,9 \\
\hline Petroleum producers & 265.708 & 3,8 \\
\hline Others & 23.566 & 0,3 \\
\hline TOTAL & 7.026 .362 & 100 \\
\hline
\end{tabular}

(Source: Commercial bank of Congo BCC)

In the light of the above table, it can be seen that the main contributors to the mobilization of State revenues are: the DGI, the DGDA and the DGRAD with a share of $96 \%$ of total revenues mobilized. It should also be noted that revenue from internal activities accounted for $91 \%$ compared with $9 \%$ from external activities.

\section{Revenues and Expenditures of the Congolese Economy}

DRC is a small open economy with a population of approximately 90 million, $61 \%$ of which live in rural areas. This gives it the status of a predominantly rural country. Like most developing countries, the Congolese economy is based on exports of raw materials and imports of consumer and capital goods. This reflects an almost total dependence on the outside world. At the local level, the market is not diversified. It is characterized by the predominance of the informal sector organized around small commercial activities and very little mobilization of savings, both private and public. Without question, the mining sector is the lifeblood of the Congolese economy. The fragility of the Congolese economy exposes it to a very large shock in the face of recent economic contractions caused by the lockdown. The International Monetary Fund has revised the DRC's growth projections to $-2.2 \%$ compared to 
the October 2020 projections which estimated the DRC's growth rate at 3.2\%5 [1]. The 2020 Finance Law positioned the DRC's budget in balance at 18,545.2 billion CDF. Taking into account the macroeconomic framework, this amount had been modified to 13,869 billion $\mathrm{CDF}$. The major problem of budget management in the DRC is reflected in successive deficits caused by a weakness in terms of revenue mobilization with the corollary of frequent recourse to printing money. For example, during the month of February, the country recorded a deficit of 180 billion CDF. The structure of spending is also problematic. During the month of February, remuneration and operating expenditures out of total expenditures accounted for $77.9 \%$ of total expenditures while investment expenditures which were $0.2 \%$ in January stood at $2.5 \%$ in February 2020. The DRC's revenues come mainly from mining royalties. In 2019, more than $90 \%$ of the country's export revenue came from foreign sales of mining products and hydrocarbons. Mining export revenues help to provide the Congolese economy with foreign exchange and maintain a balance in the foreign exchange market.

\subsection{Effects of the Covid-19 Pandemic \\ a. Economic Growth}

In the macroeconomic framework underlying the preparation of the 2020 government budget, the government projected a growth rate of 5.4\%, resulting mainly from the dynamism of the mining sector. But given the developments since the beginning of the year, the outlook remains bleak. Given China's weight in global demand for minerals (i.e., a demand for 35\% of the minerals produced by the DRC), the slowdown in its growth will obviously have an impact on the price of raw materials, including copper and cobalt. Indeed, in the first two months of 2020 , China's industrial production index fell by $13.5 \%$ compared to the corresponding period of 2019 , while retail sales fell by $20.5 \%$ in the same period. This is the largest decline seen in nearly 30 years. As a result, in March 2020, the price of copper was observed to fall by $4.87 \%$ and cobalt by $2.19 \%$ under the influence of the Chinese economic slowdown [1]. Given the elasticity of supply in relation to price, and in view of the above indicators on the evolution of the Chinese economy, DRC's current leading trading partner, we should expect a slowdown in mining activity in DRC of around $20.6 \%$. This should lead to a decli ne in economic activity in other segments of the economy and a major slowdown in Congolese growth to $0.1 \%$ in 2020 from $4.5 \%$ in 2019 in a relatively optimistic case. In the pessimistic case, the Congolese economy would fall into recession like other countries on the planet, such as those of the European Union, which is already preparing for it. According to the demographic growth rate of $3.5 \%$, a growth rate lower than $3.5 \%$ would lead to a rapid destruction of national wealth, resulting in the impoverishment of the population.

The effects of the Coronavirus pandemic on the other compartments of the economy are described below with underlying assumptions. The impact of the pandemic on the Congolese economy would therefore be twofold: via the widening of the budget deficit, and via the deterioration of the balance of payments. This will inevitably lead to a recession in the Congolese economy if appropriate budgetary support and macroeconomic reforms are not rapidly implemented.

\section{b. Public Finances}

The decline in global demand will also have a negative effect on the productive sectors and on the supply of national production, which will cause a slowdown in economic activity in DRC. The deterioration of the balance of payments will in turn have a negative effect on government revenues, which are heavily dependent on income from the sale of raw materials, the price of which has fallen sharply on the world market [1]. 


\subsection{Recovery Efforts}

Since the world is experiencing an unprecedented health crisis from December 2019, according to almost all opinion, this crisis triggered in China, and spread around the world exposing all projections of global economic growth to the risk of recession.

Last April, the International Monetary Fund (IMF) revised its 2020 global economic growth forecast, projecting a $3 \%$ contraction in the world economy. This recession, is much more severe than during the financial crisis of 2008-2009 (-0.1\%).

In the face of this crisis, which is causing a two-way shock, of both offer and demand, economic policy plays a very different role. To stem ordinary crises, policymakers try to provide an accelerated and rapid boost to economic activity by stimulating aggregate demand. However, this demand-side mechanism is becoming difficult, at least for the most affected sectors. Some governments are thinking about economic stimulus policies and budgets while other states are not yet thinking about it. Countries importing food and equipment and exporting raw materials like DRC are likely to suffer a very big shock and have a low capacity for recovery. All over the world, governments are thinking about the post-crisis period.

\section{a. In the USA}

In the United States of America, President Trump has signed a stimulus package of about US $\$ 2,000$ billion. The stimulus is about economic recovery and job creation. This fund will financially support the Americans most affected by the crisis and to extend unemployment insurance. Credits and grants will also be provided to businesses and the supplement will facilitate access to health care.

\section{b. In Europe}

500 billion agreements were signed by European finance ministers on the economic response to Covid-19. The compromises for the recovery fund are not yet acted upon and speculations accounted it to 1500 billion euros.

\section{c. China}

As for China, it plans to invest nearly 394 billion USD to revive its economy by investing massively in infrastructure. As at the beginning of the 2008 crisis, China had already revived its economy through investment in infrastructure such as the construction of roads, bridges and railroads. In 2020, the recovery will focus on areas that can help China move towards the high-tech and service-driven economy. As an example, China will invest in big data centers, $5 \mathrm{G}$ infrastructure and qualified stations of new energy vehicles (NEVs) [5].

\section{d. In Africa}

On the African continent, projections by the Economic Commission for Africa estimate that the crisis will plunge nearly 27 million people into extreme poverty. A $\$ 100$ billion fund is needed to protect and contribute to the shared prosperity of the continent [5]. According to the African Bank of development, nearly 50 million Africans will be victims of extreme poverty as a result of the COVID 19 pandemic; and this, as a result of the global economic crisis due to this pandemic, because between 2020 and 2021, Africa would lose in terms of economic income $1 / 4$ of trillions of dollars and a contraction of $3.4 \%$ of GDP would be noticed. The risk of decline would be justified by the decline in oil production by the main exporting countries including Algeria, Nigeria and Angola; in addition: the decline in prices of raw materials on the world market, the volatility of global financial conditions and natural disasters [6]. 


\section{e. In DRC}

In order to address the effects of the pandemic, a multi-sectoral emergency mitigation program for Covid-19 was officially launched on June 18, 2020. The Resident Coordinator of Operational Activities of the United Nations System in the DRC, Mr. David Mclacklan-Kar, indicated at the launch of this program that the United Nations System has produced a United Nations System Development Cooperation Framework (UNSDCF) 2020-2024.

In addition, a United Nations plan to support the Immediate Socio-Economic Response to Covid-19 in DRC has been drawn up, based on an amount of 203 million USD available and 204 million USD to be mobilized; it should be noted that this emergency program is based on three axes:

- Response, surveillance and strengthening of the health system;

- Support for macroeconomic stability and recovery of the national economy through support for essential economic activities likely to mitigate the shock caused by Covid-19 and to support the productive sectors; promotion of a minimum package of structuring and industrializing infrastructure as well as the implementation of specific measures of monetary, budgetary and exchange rate policies

- Risk mitigation and support for the population.

\subsection{Contribution of the Agricultural Sector to the Congolese National Economy}

The Congo Basin is one of the world's largest and most important tropical forest biomes/ecosystems in terms of abundance and diversity of both animal and plant species [7]. DRC represents about $10 \%$ of the world's forests and more than $47 \%$ of Africa's forests [8]. From a balanced situation between food imports and agricultural exports in the 1980s, DRC today is totally dependent on food imports [9]. Indeed, in 1960, DRC's agricultural exports represented $40 \%$ (with coffee, palm oil, rubber, cotton, sugar, tea and cocoa as the main export products); $57.9 \%$ in 1997; 10\% in 2006 and $37.4 \%$ in 2018.

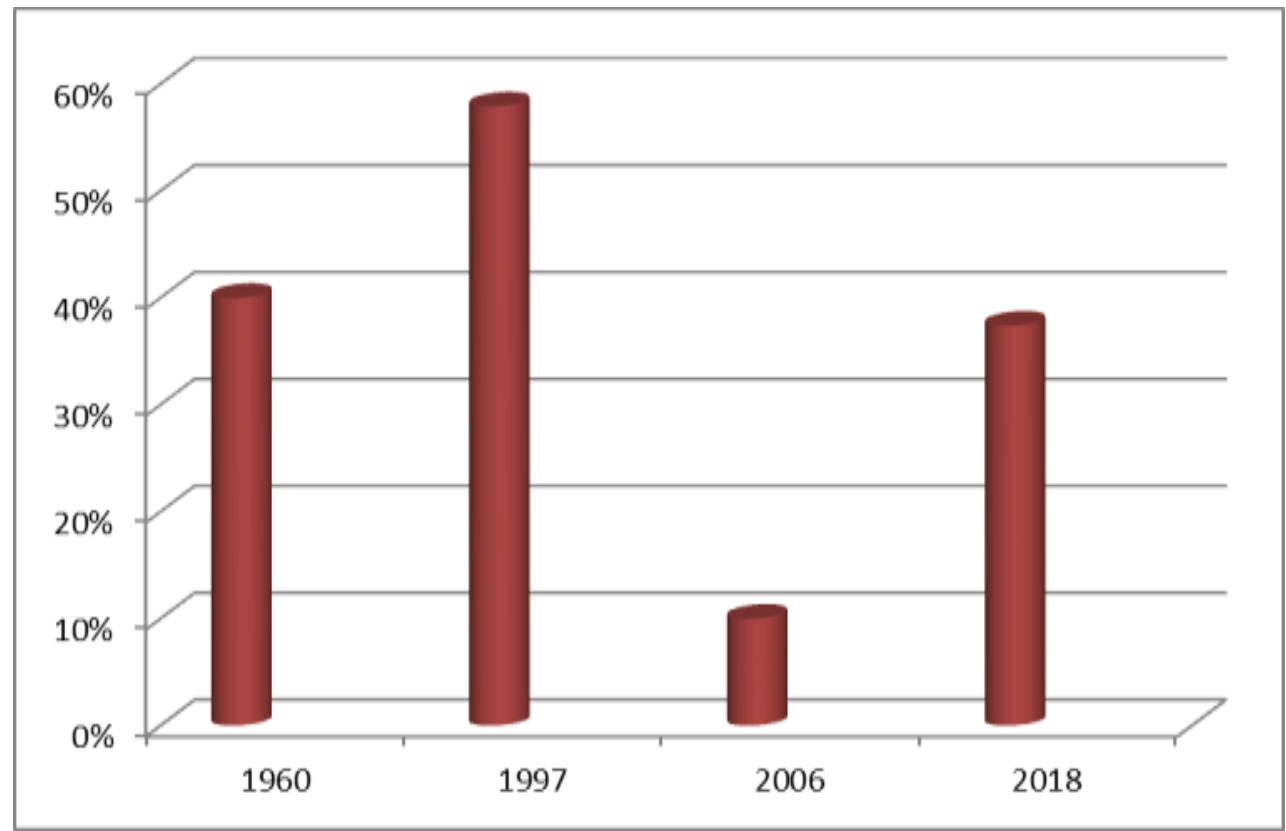

Figure 2. Contribution of the Agricultural Sector to the Congolese National Economy

After copper and crude oil, coffee and rubber were the third and fourth largest exports, respectively. The country's economic situation has been marked by robust economic growth. Between 2010 and 2012, GDP grew, in real terms, by an average of 7\%, reaching 
8.5\% in 2013 and $8.9 \%$ in 2014, exceeding the average for Sub-Saharan African countries. Between 2010 and 2013, the agricultural sector contributed 7.8\% to economic growth, suggesting its decline relative to other sectors of the economy, such as mining, trade and construction. This poor performance is due, among other things, to the use of poorly performing plant material, the low use of modern inputs, the persistence of manual operations, and the extremely low level of financing for the sector. In 2014, the agricultural sector contributed $18.3 \%$ to the formation of GDP and still occupies a significant share of the population: $64 \%$ of the total population [10], which suggests a lower productivity of the agricultural sector compared to other sectors of the national economy.

The budgets allocated to the agricultural and rural sectors, in their execution, amounted to $3.67 \%$ of the overall State budget, if we add to the expenditures of the Ministries directly involved $(2.03 \%)$ the so-called "off-budget" expenditures $(1.64 \%)$, which do not follow the usual ministerial channels, but which are nevertheless, fundamentally, expenditures made by the State. Moreover, when we consider the expenditures devoted by the Technical and Financial Partners to the agricultural and rural sector, based on the logic that these expenditures are, in their great majority, the fruit of official partnerships between DRC and its partners. We estimate that public expenditures on the agricultural and rural sector reach 5.9\% of total public expenditures, which is still far from the Maputo criterion of allocating at least $10 \%$ of the budget to the agricultural and rural sector, a target that is thus proving difficult to meet for DRC.

For those provinces for which budgetary data is available, the average budgetary expenditure in the agricultural and rural sector does not exceed $1 \%$. This situation is deplorable, especially since this sector should be much more active in the provinces than in the functioning of the administrations in urban areas [11].

\subsection{Our Contribution to the Revival of the Congolese Economy in this Period of Global Health Crisis of Covid-19}

DRC is one of the few African countries to possess a wide range of assets for its agricultural development; with its 80 million hectares of arable land, of which barely $10 \%$ is developed. DRC constitutes the 2 nd country on the planet in terms of available arable land after Brazil. Thanks to the diversity of climates and the density of the hydrographic network, DRC, fully developed, would be able to feed nearly 2 billion people, which is a major asset in the context of the global food crisis that is already looming in the long term [8].

The availability of land and the enormous water resources that the country has at its disposal with the Congo River watershed allow for the hope of greater food self-sufficiency that the Congolese people insist on. However, this agricultural potential remains largely untapped [12]. Given these changes that affect and will affect all continents and most African countries, aggravated by the corona virus pandemic, DRC could become one of the great agricultural countries of the continent and the planet. It is undeniable that the development of agriculture will be the engine of its economic revival and the main means of fighting hunger in a sustainable way in this period of global health crisis.

In view of all the above and to achieve this, the Congolese Government must develop a production policy based on the internal mobilization of resources. This mobalization would involve:

- The implementation of a National Agricultural Investment Plan (NAIP);

- The industrialization of the Agricultural Credit Bank that will grant bank credits to farmers identified following the size of their farms; 
- The creation of a technical unit for monitoring and the evaluation of the implementation of the aforementioned plan (CTSEPNIA).

\subsection{Sources of Funding}

Funding sources will be both internal and external; and to achieve that, following strategies and measures need to be adopted:

- Reducing the cost of living of political institutions (emoluments, operating expenses of the Presidency of the Republic, the National Assembly, the Senate and the Government);

- A significant reduction in non-productive expenses, the gain from which could constitute productive investment funds;

- The significant reduction or suspension of the operating costs of non-productive public institutions that drain the state budget for free;

- The recovery of all the sums lost in the past as a result of the lightness in the management of public institutions. In this case, logistical and financial support to the judicial body would help the Congolese state to recover a good part of its wealth lodged in the accounts of individuals.

Thus, the gain obtained on all the funds collected will be used to invest in the agricultural sector by developing not only subsistence Agriculture for the supply of the national market and the continuous improvement of food security but also the reduction of imports and the increase of exports (Maize, peanuts, cassava, rice, banana, etc.) as well as cash Agriculture (Palm Oil, Rubber, Green Coffee, Palm Oil, Cocoa, Tea) for commercialization. This could allow DRC to rebuild its trade balance with regard to agricultural products whose figures are not interesting.

From this investment in the agricultural space, the results obtained will certainly have a positive impact on the other spaces or sectors of the national life (industrial, communication and human) as illustrated in the figure 3.

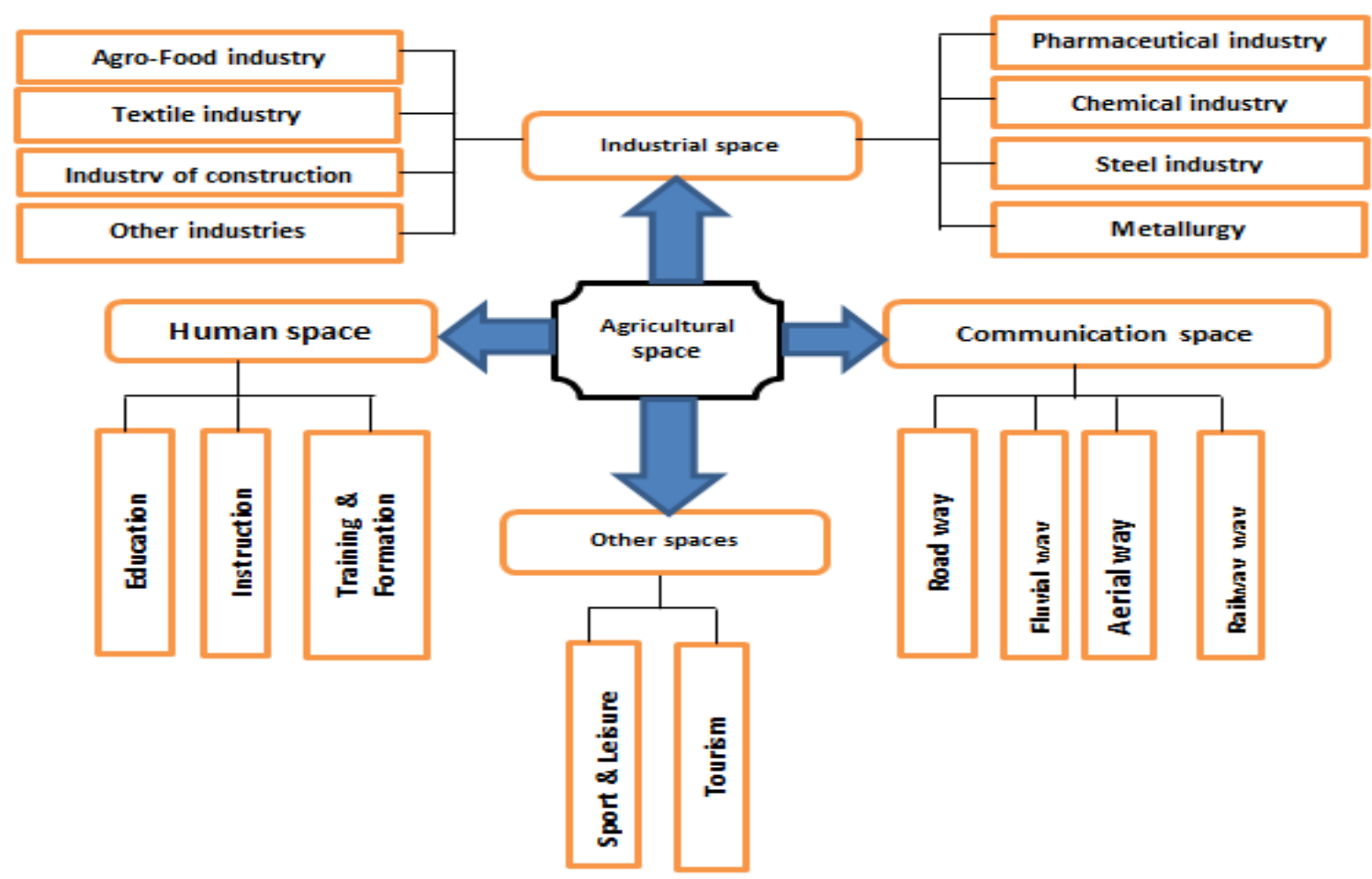

Figure 3. Impact of Agricultural Sector on Sectors of the National Life 


\section{Conclusion}

"The Democratic Republic of Congo has the capacity to feed the entire continent of Africa, even if the number of inhabitants were to increase; unlike other African countries, it is the only one that is resilient to climate change," exclaimed Alexis Bonté, acting representative of the United Nations Food and Agriculture Organization (FAO). The agricultural potential of the DRC is unanimously recognized as considerable. This land availability and the enormous water resources available to the country with the Congo River basin allow for the hope of greater food self-sufficiency that the Congolese people insist upon. However, this agricultural potential remains largely untapped. With the global health crisis caused by the corona virus, there is reason to project a credit crunch in foreign capital markets. Although the International Monetary Fund approved on April 22, 2020 a budget support (Rapid Credit Facility) of the order of 363, 27 million dollars for the DRC. Everything suggests that to finance economic recovery in DR Congo, economic policies, leaning much more on the offre side, must focus on the most productive sectors in the short term, notably, the agricultural sector. Agriculture being a source of economic growth and development of States, this period of world health crisis of Covid-19 offers a propitious opportunity for the Democratic Republic of Congo to be able to relaunch its economy from its agricultural space and therefore, to boost the activities of other sectors namely: the industrial; the Communicational; the Human Space and other spaces and thus regain a place of choice in a world economy that does not cease to globalize.

\section{References}

1. Matata PM (2020). Effets potentiels du coronavirus sur l'économie de la République démocratique du Congo. http:// congochallenge.cd

2. David de la Croix \& Baudin T (2015). La croissance économique. LIDAM Discussion Papers IRES (Institut des Recherches économiques et Social) 2015021, Université Catholique de Louvain : Belgique.

3. Beiton A, Carzola A, Hemdane E (2001). Dictionnaire des Sciences économiques, Armand colin. ISBN : 2-200-26432-1.

4. https://stopcoronavirusrdc.info

5. Nyamugira BA, Borauzima ML, Ngongo MH (2020). COVID-19 en République démocratique du Congo : Comment financer la relance économique après la crise ? doi : 10.13140/RG.2.2.36424.06407/1. Banque Africaine de développement (2020). https://www.afdb.org

6. Ngbolua KN (2018). Données préliminaires sur la biodiversité du Nord-Ubangi en République démocratique du Congo. Editions Universitaires Européennes, Riga : Latvia. ISBN : 978-613-8-44529-6.

7. Ministère de l'Environnement, Conservation de la Nature et Tourisme, MECNT (2014). Cinquième rapport national sur la mise en œuvre de la Conservation sur la Diversité Biologique, République démocratique du Congo.

8. Code Agricole, République démocratique du Congo (2008). http://www.inter-reseaux.org

9. Les mythes de la Banque Mondiale sur l'agriculture et le développement (2014). https://www.oaklandinstitute.org

10. Ministère de l'Agriculture et du Développement Rural (2015). Revue diagnostique des Dépenses Publiques de base du secteur Agricole et Rural «RDPA», République démocratique du Congo (2007-2013).

11. Bolakonga IAB, Nkulu JMF, Mushakulwa W (2017). Les filières agricoles en République démocratique du Congo : Maïs, riz, bananes plantains et pêche, Publications de la Fondation Konrad Adenauer. www.kas.de 